\section{EXPLORING COMPUTER ASSISTED LEARNING FOR LOW ACHIEVING ChILDREN: A Comparative ANALYSIS STUDY}

Siti Zulaiha Ahmada*, Ariffin Abdul Mutalibb

aUniversiti Teknologi MARA Perlis, Malaysia

bSchool of Multimedia Technology and Communication, sitizulaiha@perlis.uitm.edu.my Universiti Utara Malaysia, Kedah, Malaysia
Article history

Received

8 February 2015

Received in revised form

1 September 2015

Accepted

11 October 2015

*Corresponding author

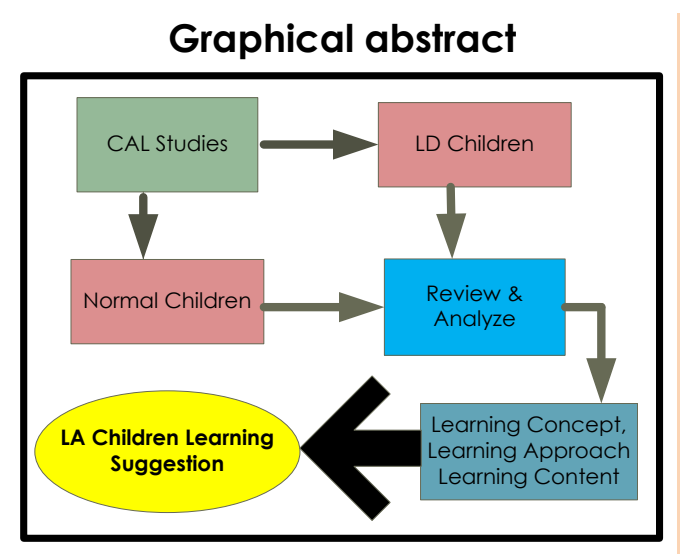

\section{Abstract}

Learning assistance or support is essential for a learner regardless of their cognitive ability and learning preference. Computer assisted learning (CAL) is one of the facilitation that widely explored as alternative learning assistances with different concepts, approaches, contents and target users. The main concern of this study is to explore and identify learning concepts and approaches that have been employed in previous research for normal and learning disabilities learners. In relation with the intention, 15 articles from past five years (2010-2015) are selected for review and analysis processes in this comparative analysis study. The finding shows some similarities and differences of CAL concept and approach for both type of learners. Some insights and suggestions are drawn based on the extracted concepts and approaches specifically for low achieving children as their learning assistance in primary school.

Keywords: Low achieving children, learning assistance, learning concept, learning approach, computer assisted learning

\begin{abstract}
Abstrak
Bantuan pembelajaran adalah penting bagi setiap pelajar tanpa mengira kebolehan kognitif dan kecenderungan pembelajaran. Pembelajaran Berbantukan Komputer (PBK) adalah salah satu alat bantuan yang telah diterokai secara melvas sebagai alternatif alat bantuan pembelajaran dengan penerapan kelainan dari segi konsep, pendekatan, kandungan dan pengguna sasaran. Perkara utama yang diberi perhatian dalam kajian ini ialah untuk meneroka dan mengenal pasti konsep dan pendekatan pembelajaran yang digunapakai dalam kajian-kajian lepas terhadap pelajar normal dan bermasalah pembelajaran. Oleh yang demikian, 15 artkel yang diambil dari 5 tahun sebelum ini (2010-2015) telah dipilih untuk diulas dan dianalisis dalam satu kajian analisis perbandingan. Hasilnya menunjukkan persamaan dan perbezaan bagi kedua-dua jenis penguna dalam PBK yang berkaitan. Di samping itu, beberapa pandangan dan cadangan diutarakan bagi pihak pelajar berpencapaian rendah.

Kata kunci: Kanak-kanak berpencapaian rendah, bantuan pembelajaran, konsep pembelajaran, pendekatan pembelajaran, pembelajaran berbantukan komputer
\end{abstract}




\subsection{INTRODUCTION}

Computer assisted learning (CAL) is essential and widely used in today's digital environment given in schools, universities, and other institutions. The main intention is to facilitate the learning process as it could impose diversity of learning activities and induce a deep learning among the learners. Basically, many CALs have been developed based on enormous research conducted across the world such as assistive courseware using multimedia [1]-[3] and proven the effectiveness towards the learners. Most of these applications are introduced within specific target users with special technological treatments including for low achieving (LA) children.

LA children is a group of children that need special attention as they need a longer time to acquire understanding conceptually and practically in learning process [3] with IQ test scores between 70 and 90 [4], [5] and usually get lower scholastic achievement in common examinations [6]. However, LA children are not eligible for special education [4], [5] because they only have slight differences in learning ability from normal children that are below average academic standard [5]. Specifically, in Malaysian education system, most of these children are unable to complete the LINUS test [7] and need a close guidance by teachers to complete the test. This problem may deteriorate the children's confidence and self-motivation when they proceed to higher level of education system.

Fortunately, previous studies have shown that learning difficulties among children are best mediated with computer-based learning intervention such as in learning mathematic [8], [9], reading assistance [3], improving English language [10] and writing [11]. However, limited studies have been conducted to investigate the suitable concept in CAL for underperforming of non-learning disabilities children. Therefore, this study intends to identify and review CAL that have been conceptually or practically introduced in the past 5 years $(2010-2014)$ and to seek how this technology can be adapted especially for LA children.

\subsection{METHODOLOGY}

This study has been conducted qualitatively using comparative study technique with steps seen in Figure 1. In order to initiate the study, an exhaustive literature search has been done by exploring numerous global journals and databases to obtain articles that are related to computer-based learning assistance in the past five years $(2010$ - 2014) from various countries. Several keywords that have been used for searching such as "computer assisted learning", "learning assistance for low achievers", "low achiever courseware in Malaysia", "interactive courseware for children" and some other related keywords.

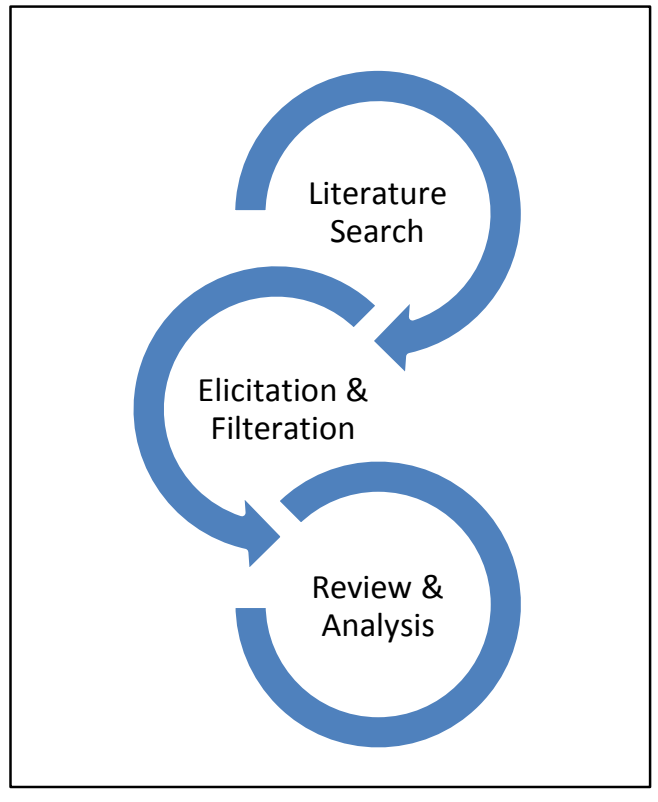

Figure 1 Methodology of the study

In the early stage of literature search, there were more than 50 articles have been listed where only computer based learning studies was considered. Those articles were manually elicited and filtered using specific pre-determine themes in order to obtain intended article's concept based on this study. The 15 extracted articles are related to the relevant research which targeted for normal and learning disabilities (LD) learners as well as for education intervention purposes. Those articles were reviewed and analyzed in term of their learning approach and learning assistance concepts that have been implemented in different study setting and countries (eight from Malaysia and seven from other countries).

\subsection{REVIEWED WORKS}

There have been many studies conducted in the area of teaching and learning that utilize computer as learning assistance. Most of the studies (with some of it still in proposing stage) uniquely adapted learning concept that can facilitate the learners to internalize the knowledge and promote an effective learning approach. In order to analyze suitable concept of learning assistance for LA children in-depth, the following 15 works have been reviewed.

\section{1 e-WayCOOL (\#1)}

Inspired by national heritage concept, a study conducted by Jasni and Zulikha [12], incorporates wayang kulit features, deep-learning and multisensory approaches in an application named e-WayCOOL. It is specifically designed for Level 1 primary school children in learning basic mathematics to promote fun 
and enjoy learning concept. Implementation of the learning concepts was supported with interactive multimedia technology which has been proven applicable for children to absorb fundamental knowledge in educational context.

\subsection{VilLE Education Tool (\#2)}

A study that was conducted in Finnish primary school has proven that computer-based learning assistance with collaborative learning can give a significant impact towards learning process [13]. It is conducted using ViLLE platform, which consists of visualization features of mathematical learning with immediate feedback for the interaction. The web-based application was developed using multimedia learning approach to present fraction topic for grade three students using verbal and visual elements. The intervention evaluation results show that students positively accepted the learning concept and engaged in the learning process.

\subsection{MyLINUS (\#3)}

According to Wan Ahmad [3], slow learners (LINUS children) need special attention in assisting them during the learning process. Reading assistance called MyLINUS, specially developed for these children is based on the LINUS learning syllabus in Malaysian education context, which also consists of game-based concept using multimedia approach. The main concern is to motivate and encourage the children in reading and at the same time can be used by teachers as an alternative teaching material.

\subsection{Interactive E-Book Learning System (IELS) (\#4)}

The main intention of IELS is to engage elementary learners in personalized learning concept by incorporating interactive elements using multimedia learning approach to strengthen their focus and attention in reading. In short, IELS can be concluded as a practical learning assistance with the learning concept and approach adapted to facilitate the students, which has been proven effective through a usability evaluation [14].

\subsection{Li2D (\#5)}

Li2D is an application that implements a repetitive learning with well-planned teaching concept, which is embedded in game-based environment using multimedia learning approach. The prototype is designed according to the numerous concept of learning theories and design theories with specific mathematical topics for secondary school learners. Basic idea of the courseware is to cultivate the effective learning approach and at the same time to produce a highly usable and motivational learning tool [9].

\subsection{Computer Assisted Mathematical Problem Solving System (\#6)}

A study was conducted in Taiwan by applying Polya's problem solving model using problem-based learning concept [15]. Basic mathematical addition and subtraction operations have been implemented in a web-based system environment. A systematic guided instruction is used to assist the students in extracting arithmetic procedures for word-based question. The system was developed specifically for middle and elementary levels regardless of their academic achievement.

\subsection{Multimedia Interactive Program (\#7)}

The study by Nusir and friends [16] was conducted in Jordan, which involved primary school children aged 7 years old. Researchers employed common interactive multimedia component that incorporates media enhanced format using cartoon characters, using game-based learning concept to acquire basic mathematics skills in fraction topics. Testing results show that integration of both concepts significantly improves learning performance of the children.

\subsection{Technological Persuasive Pedagogy (\#8)}

Technological pedagogy is the main ingredient in this study by considering persuasion concept in teaching and learning. A series of studies have been conducted in terms of introducing a new concept of learning for primary school children to learn mathematics using computer-based application [17], [18]. The focal point of the study is to persuade and encourage children in mathematical learning as most of them feel that mathematics is difficult and always show negative attitude towards mathematics learning.

\subsection{Interactive Multimedia Learning Object (IMLO) (\#9)}

IMLO applies motivational learning with story-based concept using interactive multimedia learning environment, in which the designers incorporates the main components from Attention, Relevance, Confidence, and Satisfaction (ARCS) model into the application. It is specifically developed for dyslexia children to facilitate them in learning mathematics as well as to motivate their learning interest. The content of IMLO is based on the Malaysian education syllabus. Overall, the use of special multimedia instructions suggested in IMLO have been positively reviewed by the experts [19].

\subsection{E-learning Framework (\#10)}

This study focuses on the technological intervention in e-learning environment for all types of learning disabilities (LD), which include individualized learning and remedial learning using different concepts. The study pointed out that those technological interventions have direct implication on LD learners 
[20]. Thus, they suggested that individualized learning could utilize rich multimedia learning elements such as images, audio, and video while practice session can be conducted for remedial learning. The study also put motivational learning concept into consideration, which is believed can give positive effects towards their academic performance.

\subsection{Multisensory Multimedia Learning Support (\#11)}

The application that applies multi-sensory concept, which is integrated with interactive multimedia approach in reading courseware for dyslexia children, has shown a clear picture of an effective learning concept. Sidhu and Manzura [21] found that multisensory learning concept with phonic reading and eclectic-Express are applicable for dyslexia children as the experimental tests revealed a positive result. Besides that, an application that is incorporated with suitable learning styles designed for dyslexia children also have been taken into consideration in the courseware.

\subsection{Math Explorer (\#12)}

Amiripour and friends [1] explored the concept of assistive technology instruction that has been deployed in Math Explorer software developed by Woo and Seo in 2009. Math Explorer is a mathematical learning software that is implemented using persuasion concept and guided instructional model. Additionally, it is coined with interactive activities using do-askcheck approach to increase users' motivation and problem solving capabilities.

\subsection{My Computer (\#13)}

Initiated by learning problems faced by slow learner children, Wan Fatimah [22] suggested a thematicbased activity by including game-based learning concept. The study proposed a multimedia learning courseware namely, My Computer, to capture users' learning interest and motivation based on the Special Education School syllabus content in Malaysian context, which has been proven as usable.

\subsection{4 "Bijak Membaca" (\#14)}

The study was conducted for dyslexia children who have problem in reading Malay. Multi-sensory concept and interactive multimedia learning with phonic reading technique were applied as the basis of the application. "Bijak Membaca" courseware is specifically design to suite dyslexic characteristics. The study found that the integration of those learning concepts as learning strategies in an application for reading assistance has shown a significant impact towards dyslexic reading skill [23].

\subsection{Assistive Learning Environment (ALE) (\#15)}

Assistive learning environment is an approach studied by Pirani and Sasikumar [24] to be implemented using interactive learning management system. As proposed in the ALE, it consists of comprehensive and adaptable pedagogical strategies based on the student behavioral profile, which support their learning style. It is applicable for all types of LD learners. The main intention of the study is to provide a proper learning environment of LD learners that best suited based on their level of disabilities.

\subsection{FINDINGS}

Extraction from the above discussion is exhibited in Table 1. It shows the summary of the learning approach and learning assistance concept. The first eight studies are related to normal learners and the rest are related to learners with learning disabilities, in which 13 studies are related to children learning needs while the remaining studies highlighted adult and general user needs. The main reason for choosing the different target users is to explore the trends of CAL studies in educational context.

Based on the analysis of each study, most of the studies (10 studies) have proven the effectiveness of the application or software except for the other five studies, which are related to conceptual model with extensive study. There are similarities and varieties of learning assistance concept, learning approach, and learning content that have been implemented in each studies.

Having extracted from the review, the results are detailed in Table 2. It is seen in Table 2 that there are eight learning approaches (multisensory guided instruction/personalized, deep learning, game based, story-telling, problem based learning, persuasive / motivational and collaborative / cooperative), two learning assistance concepts (web-based system and interactive multimedia) and three learning contents (literacy, numeracy, and general) that are frequently chosen for educational applications or studies.

The distribution of those categories for both types of target user is also exhibited in Table 2. It is seen that four learning approaches are mostly found among 15 selected articles. They are multisensory, personalization or guided instruction, game-based and persuasion learning approaches. It is also found that multimedia learning concept are mostly implemented among all with numeracy learning content is catered at most.

Accordingly, this finding will be further discussed in the next section on how it can be utilized for LA children CAL concept. 
Table 1 Learning concept and approach from previous studies

\begin{tabular}{|c|c|c|c|c|c|c|c|c|c|c|c|c|c|c|c|}
\hline \multirow{2}{*}{$\begin{array}{l}\text { Target group } \\
\text { Study }\end{array}$} & \multicolumn{8}{|c|}{ Normal } & \multicolumn{7}{|c|}{ LD } \\
\hline & 1 & 2 & 3 & 4 & 5 & 6 & 7 & 8 & 9 & 10 & 11 & 12 & 13 & 14 & 15 \\
\hline Software availability? & $\sqrt{ }$ & $x$ & $\sqrt{ }$ & $\sqrt{ }$ & $\sqrt{ }$ & $\sqrt{ }$ & $\sqrt{ }$ & $x$ & $\sqrt{ }$ & $x$ & $x$ & $\sqrt{ }$ & $\sqrt{ }$ & $\sqrt{ }$ & $x$ \\
\hline Level (C/A/G) & C & C & C & C & $A$ & C & C & C & C & $G$ & C & C & C & C & C \\
\hline \multicolumn{16}{|c|}{ Learning approach } \\
\hline Multisensory & $\sqrt{ }$ & & & & & & & & & & $\sqrt{ }$ & & & $\sqrt{ }$ & \\
\hline Guided instruction/Personalized & & & & $\sqrt{ }$ & & & & & & $\sqrt{ }$ & & $\sqrt{ }$ & & & $\sqrt{ }$ \\
\hline Deep Learning & $\sqrt{ }$ & & & & & & & & & & & & & & \\
\hline Game based & & & $\sqrt{ }$ & & $\sqrt{ }$ & & $\sqrt{ }$ & & & & & & $\sqrt{ }$ & & \\
\hline Story-telling & & & & $\sqrt{ }$ & & & & & & & & & & & \\
\hline Problem based learning & & $\sqrt{ }$ & & & & $\sqrt{ }$ & & & & & & $\sqrt{ }$ & & & \\
\hline Motivational/Persuasive & & & & & & & & $\sqrt{ }$ & $\sqrt{ }$ & & & $\sqrt{ }$ & $\sqrt{ }$ & & \\
\hline Collaborative/Cooperative & & $\sqrt{ }$ & & & & & & & & & & & & & \\
\hline \multicolumn{16}{|c|}{ Learning assistance concept } \\
\hline Web-based system & & $\sqrt{ }$ & & & & $\sqrt{ }$ & & & & & & & & & $\sqrt{ }$ \\
\hline Interactive multimedia & $\sqrt{ }$ & & $\sqrt{ }$ & $\sqrt{ }$ & $\sqrt{ }$ & & $\sqrt{ }$ & $\sqrt{ }$ & $\sqrt{ }$ & $\sqrt{ }$ & $\sqrt{ }$ & $\sqrt{ }$ & $\sqrt{ }$ & $\sqrt{ }$ & \\
\hline \multicolumn{16}{|c|}{ Learning content } \\
\hline Literacy & & & $\sqrt{ }$ & $\sqrt{ }$ & & & & & & & $\sqrt{ }$ & & & $\sqrt{ }$ & \\
\hline Numeracy & $\sqrt{ }$ & $\sqrt{ }$ & & & $\sqrt{ }$ & $\sqrt{ }$ & $\sqrt{ }$ & $\sqrt{ }$ & $\sqrt{ }$ & & & $\sqrt{ }$ & & & \\
\hline General content & & & & & & & & & & $\sqrt{ }$ & & & $\sqrt{ }$ & & $\sqrt{ }$ \\
\hline
\end{tabular}

C-Children; A - Adult; G-General 
Siti Zulaiha Ahmad \& Ariffin Abdul Mutalib / Jurnal Teknologi (Sciences \& Engineering) 77:29 (2015) 1-7

Table 2 Distribution of Learning approaches, concept and content for normal and learning disabilities user

\begin{tabular}{|c|c|c|c|}
\hline Item & Normal & LD & Total \\
\hline \multicolumn{4}{|l|}{ Learning approach } \\
\hline Multisensory & 1 & 2 & 3 \\
\hline Guided instruction/Personalized & 1 & 3 & 4 \\
\hline Deep Learning & 1 & 0 & 1 \\
\hline Game based & 3 & 1 & 4 \\
\hline Story-telling & 1 & 0 & 1 \\
\hline Problem based learning & 2 & 1 & 3 \\
\hline Motivational/Persuasive & 1 & 3 & 4 \\
\hline Collaborative/Cooperative & 1 & 0 & 1 \\
\hline \multicolumn{4}{|l|}{ Learning assistance concept } \\
\hline Web-based system & 2 & 1 & 3 \\
\hline Interactive multimedia & 6 & 6 & 12 \\
\hline \multicolumn{4}{|l|}{ Learning content } \\
\hline Literacy & 2 & 2 & 4 \\
\hline Numeracy & 6 & 1 & 7 \\
\hline General content & 0 & 3 & 3 \\
\hline
\end{tabular}

\subsection{CONCLUSION}

Computer-based learning is important in facilitating students in learning process as a learning assistance by implementing specific learning concept, approach, and content. Numerous previous studies have proven that learning assistance continually needs some refreshment in terms of learning approach and concept within a proper learning content.

Based on the review it can be inferred that numeracy or mathematics and literacy content such as English language and Malay language for Malaysian education context are frequently chosen, in which most of them based on interactive multimedia learning. It shows that interactive multimedia in form of creative courseware content is much suitable as learning concept for children who require interesting, entertaining, engaging and exciting learning medium with graphical and emotional attractiveness [2], [25], which can be considered for LA children.

In terms of the learning approach adaptation, there are eight approaches can be identified, which are usually implemented for children as listed in Table 2. Among all, multisensory and persuasive learning approaches are the most suitable as it could stimulate senses and increase the motivational aspect in learning process of LD children.

Besides that, it is clearly shown that game-based concept is among the popular learning concept. The main advantages of game-based learning are the interactivity and engagement concepts that can be implemented to involve the children in learning, actively [26]. The other learning approaches such as $\mathrm{PBL}$, storytelling and deep learning are also suited for children learning application, but they are rarely used among those studies.

However, implementation of those learning approaches towards LA children is infancy and needs an in-depth study. In fact, there is only one study that directly focuses on LINUS children, namely, MyLINUS. This application is specifically designed for under-achievement children who are also considered as LA children because they are under a special remedial program.

It can also be concluded that multimedia learning is the most appropriate for children for computerbased learning assistance approach with any learning content such as literacy or numeracy. A comprehensive study needs to be conducted in order to justify the suitable learning approach to the 
LA children by assessing each learning concept in terms of its advantages and effectiveness.

\section{Acknowledgement}

We are grateful for the UiTM scholarship to Author 1 and the UUM grant to Author 2.

\section{References}

[1] Amiripour, P., Bijan-zadeh, M. H., Pezeshki, P., \& Najafi, M. 2011. Effects of Assistive Technology Instruction on Increasing Motivation and Capacity of Mathematical Problem Solving in Dyscalculia Students. International Research Journal. 2(10): 1611-1618.

[2] Hoogeveen, M. 1997. Toward A Theory of the Effectiveness of Multimedia Systems. International Journal of HumanComputer Interaction. 9(2): 151-168.

[3] Wan Fatimah, W. A., Shahrina, M. N., \& Nor Syafiza, M. S. 2013. Development of a Multimedia Courseware for Slow Learner Children with Reading Difficulties: Mylinus. In Lecture Notes in Computer Science (including subseries Lecture Notes in Artificial Intelligence and Lecture Notes in Bioinformatics) Switzerland: Springer International Publishing. 8237: 371-382.

[4] Malik, N. I., Rehman, G., \& Hanif, R. 2012. Effect of Academic Interventions on the Developmental Skills of Slow Learners. Pakistan Journal of Psychological Research. 27(1): 135-151.

[5] Malik, S. 2009. Effect of Intervention Training on Mental Abilities of Slow Learners. International Journal of Education Science. 1(1): 61-64.

[6] Sani, N., \& Idris, A. R. 2013a. Identifying the Challenges Encountered by Teachers in Dealing with Indigenous Students. Malaysian Online Journal of Educational Management. 1 (3): 48-63.

[7] Sani, N., \& Idris, A. R. 2013b. Implementation of Linus Programme based on the Model of Van Meter and Van Horn. The Malaysian Online Journal of Educational Science. 1(2): 25-36.

[8] De Witte, K., Haelermans, C., \& Rogge, N. 2014. The Effectiveness of a Computer-Assisted Math Learning Program. Journal of Computer Assisted Learning. 1-24.

[9] Zuraini Hanim, Z., \& Wan Fatimah, W. A. 2011. Application of Design and Learning Theories in Multimedia Courseware Development, "Li2D." 2011 National Postgraduate Conference. 1-5.

[10] Masri, M., Mohd Nordin, S., \& Sulaiman, S. 2008. A Conceptual Framework for English Language Courseware Using Storytelling Approach: Case Study in University Teknologi Petronas. 2008 International Symposium on Information Technology. 1-6.

[11] Ahmad, S. Z., Mustafar, S. A., Ekhsan, H. M., \& Abdul, S. 2011. Write Perfect: An Interactive Multimedia Writing Aid for Dyslexic Children. In Proceeding of ASEAN Conference on Scientific and Social Science Research.

[12] Jasni, A., \& Zulikha, J. 2013. Utilising Wayang Kulit for Deeplearning in Mathematics. In Proceeding of the World Congress on Engineering 2013. II: 1-6.
[13] Kurvinen, E., Lindén, R., Rajala, T., Kaila, E., Laakso, M., \& Salakoski, T. 2012. Computer-Assisted Learning in Primary School Mathematics using ViLLE Education Tool. In Proceedings of the 12th Koli Calling International Conference on Computing Education Research-Koli Calling '12. 39-46.

[14] Huang, Y. M., Liang, T. H., Su, Y. N., \& Chen, N. S. 2012. Empowering Personalized Learning with an Interactive $\mathrm{E}$ Book Learning System for Elementary School Students. Educational Technology Research and Development. 60(4): 703-722.

[15] Huang, T., Liu, Y., \& Chang, H. 2012. Learning Achievement in Solving Word-Based Mathematical Questions through a Computer-Assisted Learning System Problem-Based Learning (PBL). Educational Technology \& Society. 15(1): 248-259.

[16] Nusir, S., Izzat, A., Al-Kabi, M., \& Sharadgah, F. 2013. Studying the Impact of using Multimedia Interactive Programs on Children's Ability to Learn Basic Math Skills. ELearning and Digital Media. 10(3): 305-319.

[17] Aris, B., Gharbaghi, A., Ahmad, M. H., \& Rosli, M. S. 2013. A Check List for Evaluating Persuasive Features of Mathematics Courseware. International Education Studies. 6(9): 125-134.

[18] Gharbaghi, A., Aris, B., Ahmad, M. H., \& Rosli, M. S. 2013. Technological Persuasive Pedagogy: A New Way to Persuade Students in the Computer-based Mathematics Learning. Journal of Education and Practice. 4(14): 43-49.

[19] Rahman, F. A., Mokhtar, F., Alias, N. A., \& Saleh, R. 2012. Multimedia Elements as Instructions for Dyslexic Children. International Journal of Education Information Technology. 6(2): 193-200.

[20] Pirani, Z., Molvizadah, V., Sayyed, M. A., \& Sasikumar, M. 2013. E-Learning Framework for Learning Disabled Children. International Journal of Computer Application. 63(19): 38-42.

[21] Sidhu, M. S., \& Manzura, E. 2011. An Effective Conceptual Multisensory Multimedia Model to Support Dyslexic Children in Learning. International of Information and Communication Technology Education. 7(3): 34-50.

[22] Abdollah, N., Wan Ahmad, W. F., \& Patah Akhir, E. A. 2010. Multimedia Courseware for Slow Learners: A Preliminary Analysis. In Information Technology (ITSim), 2010 International Symposium. 1-6.

[23] Ahmad, S. Z., Nik Ludin, N. A. A., Ekhsan, H. M., \& Rosmani, A. F. 2012. Bijak Membaca-Applying Phonic Reading Technique and Multisensory Approach with Interactive Multimedia for Dyslexia Children. In IEEE Colloquium on Humanities, Science \& Engineering Research (CHUSER 2012). 554-559.

[24] Pirani, Z., \& Sasikumar, M. 2012. Assistive Learning Environment for Students with Learning Disabilities. In 2012 4th International Conference on Intelligent Human Computer Interaction (IHCl). 1-6.

[25] Chen, C.-M., \& Sun, Y.-C. 2012. Assessing the Effects of Different Multimedia Materials on Emotions and Learning Performance for Visual and Verbal Style Learners. Computers \& Education. 59(4): 1273-1285.

[26] Barzilai, S., \& Blau, I. 2014. Scaffolding Game-based Learning: Impact on learning Achievements, Perceived Learning, and Game Experiences. Computers \& Education. 70: 65-79. 